5. Коваленко И. В. Изготовление шиньонов и париков и прически из них / И. В. Коваленко. - Ростов-на-Дону: Феникс, 2004. - 224 с.

6. Константинов А. В. Парикмахерское дело : [практ. пособ.] / А. В. Константинов. М. : Высшая школа, 1987. - 336 с.

7. Кудін В. О. Естетичне в педагогічній методології професії // Неперервна професійна освіта: теорія і практика: [зб. наук. праць] / за ред. І. А. Зязюна та Н. Г. Ничкало. - Ч.1. - К., - 2001. - С. 27-30.

8. Леонтьев А. Н. Деятельность. Сознание. Личность / А. Н. Леонтьев. - М. : Политиздат. - 1975. - 138c.

9. Леонтьев А. Н. Избранные психологические произведения / А. Н. Леонтьев. -Т. 2. М. : Педагогика, 1983. - С. 232-240.

10. Педагогическая энциклопедия / гл. ред. Каиров А. И. - М. : Сов. энциклопедия, 1988. - Т.3. - 880 с.

11. Перукарське мистецтво: [підручник для учнів проф.-тех. навч. закладів] / В. Ф. Орлов (заг. ред.). - Кн.1: Історія перукарської справи. - К. : Грамота, 2005. - 351 с.

12. Хуторской А. В. Дидактическая эвристика. Теория и практика креативного обучения / А. В. Хуторской. - М. : МГУ, 2003. - 416 с.

13. Шевченко Г.П. Взаємодія мистецтв в естетичному вихованні підлітків / Г. П. Шевченко.- К. : Знання, 1981. - 298 с.

14. Юнг К.Г. Психоанализ и искусство / К. Юнг, Э. Нойман. - К. : REFL-book, ВАКЛЕР, 1996. - С. 9-29.

Стаття надійшла до редакції 14.05.2012 р.

Г. Б. Бреславська, викладач,

Миколаӥвський національний університет ім. В. О. Сухомлинського

\title{
ПРОЕКТНА ДІЯЛЬНІСТЬ ЯК ЗАСІБ ФОРМУВАННЯ ПРОФЕСІЙНОЇ КОМПЕТЕНТНОСТІ МАЙБУТНЬОГО ВЧИТЕЛЯ
}

Бреславська Г. Б. Проектна діяльність як засіб формування професійної компетентності майбутнього вчителя.

У статті розкрито питання проектної діяльності як одного із засобів формування професійної компетентності майбутнього вчителя, висвітлено можливості застосування методу проектів у фаховій підготовиі студентів.

Ключові слова: проект, проектна діяльність, професійна компетентність

Бреславская А.Б. Проектная деятельность как средство формирования профессиональной компетентности будущего учителя.

В статье раскрывается вопрос проектной деятельности как одного из средств формирования профессиональной компетентности будущего учителя, показаны возможсности применения метода проектов в профессиональной подготовке студентов.

Ключевые слова: проект, проектная деятельность, профессиональная компетентность.

Breslavskaya A. Project activity as a means of the formation of professional competence of future teachers.

The article deals with the problem of project activity as a means of the formation of professional competence of future teachers. The author shows the possibilities of the project method for students' professional training.

Key words: project, project activity, professional competence. 
Постановка проблеми в загальному вигляді. На сучасному етапі розвитку вищої освіти стандарти підготовки спеціалістів стали розширюватися за рахунок віднесення до них не лише системи знань, а й досвіду практичної діяльності загалом і обов'язкового досвіду самостійної, $з$ елементами творчості, діяльності зокрема. Це вимагає удосконалення форм $\mathrm{i}$ методів організації та здійснення навчально-виховного процесу у вищих навчальних закладах, змінює пріоритети в підготовці майбутніх педагогів. Формуванню професіоналізму майбутніх учителів сприють засоби навчання, зокрема такі, як проектна діяльність, у процесі застосування якої реалізуються всі стадії творчого процесу людини: виникнення, обгрунтування, осмислення і прийняття ідеї, технологічна розробка ідеї, практична робота над втіленням ідеї, апробування об'єкта в роботі, допрацювання і самооцінка творчого розв'язання ідеї.

Аналіз досліджень та публікацій. Розвиток ідеї застосування методу проектів у навчальній діяльності школярів детально проаналізовано С. Гончаренком, О. Савченко, О. Фунтіковою. Особливості організації проектної діяльності студентів під час вивчення педагогічних дисциплін визначає О. Зосименко, яка наголошує, що «в освіті проекти доцільно розглядати як інноваційну форму організації освітнього середовища, в основі якої лежить самостійне розв'язання студентами значущої проблеми - від ідеї до iї практичної реалізації - під гнучким керівництвом викладача» [3].

У дослідженні О. Фунтікової метод проекту розглядається як засіб розвитку і саморозвитку професійного зростання майбутніх спеціалістів, у результаті чого формується система професійно-педагогічних умінь на підставі створення оптимальних умов організації самостійної роботи i досягнення високих результатів у навчальній роботі. Автор визначає такі функції педагогічного проекту:

1) навчальна функція, пов'язана із оволодінням теоретичними знаннями, узагальненням суттєвих фактів науки, передового педагогічного досвіду;

2) наукова функція, реалізація якої передбачає уміння студентами здійснювати спостереження, аналізувати досвід педагогічної діяльності i співробітництва педагога з дітьми відповідно до змісту проекту, узагальнювати проблему з позиції наукових методів дослідження;

3) методична функція спрямована на розроблення системи завдань та системи контролю знань відповідно до змісту проекту [7].

Метою статті $\epsilon$ висвітлення можливостей застосування методу проектів у фаховій підготовці студентів, у формуванні професійної компетентності майбутніх учителів.

Метою проектної діяльності майбутніх учителів $є$ навчальний творчий проект, під яким розуміється самостійно розроблений продукт від ідеї до ії втілення, який має суб'єктивну або об'єктивну новизну і виконаний під контролем і консультацією більш досвідченого викладача. У своїй практичній діяльності студентам, які готуються стати вчителями, ми пропонуємо взяти участь у проектній діяльності, що спрямована на створення портфоліо 
навчально-методичних матеріалів, які стануть основою їх подальшого використання під час практики, а також майбутньої професійної діяльності.

У проектній діяльності щодо створення портфоліо навчальних матеріалів використовуються положення, розроблені в програмі «Intel® Навчання для майбутнього» (США) та адаптовані українськими авторами Н.Морзе, Н. Дементієвською. Реалізація цієї програми спрямована на застосування інформаційно-комунікативних технологій у навчанні школярів. У нашому досвіді ідеї щодо створення проектів ми використовуємо у процесі формування методичної компетентності майбутніх учителів [5].

Під час підготовки проекту для використання його у процесі вивчення педагогічних дисциплін студенти готують портфель навчально-методичних матеріалів, який містить:

1) план проекту, навчальна мета якого враховує вимоги державних стандартів та навчальних програм;

2) приклади робіт, підготовлених майбутніми вчителями у ролі студентів (студентська мультимедійна презентації, студентський бюлетень чи буклет);

3) дидактичні матеріали; методичні матеріали (мультимедійна презентація, інструкції щодо організації роботи над проектом); список інформаційних джерел.

Метою такої роботи є розширення меж творчої діяльності - як власної, так і учнів; усвідомлення можливості ефективного застосування комп'ютерних технологій у вищій школі.

Для досягнення поставленої мети студентам необхідно реалізувати такі завдання:

1) узагальнити знання щодо сутності методу проектів і специфіки його застосування у школі;

2) розробити ідею проекту при вивченні конкретних тем із педагогічних дисциплін;

3) дібрати інформаційний матеріал;

4) удосконалити вміння володіння програмними засобами Microsoft Word, Microsoft Power Point, Microsoft Internet Explorer, Microsoft Publisher;

5) оформити проект, представивши його колегам по групі;

6) реалізувати проект під час практики.

У ході розроблення проектів студенти пропонують для реалізації як дослідницькі, так й інформаційні та практико-орієнтовані проекти.

У дослідницьких проектах передбачається формування гіпотези, iii перевірка, обговорення та аналіз результатів, їх оформлення. Такі проекти найбільш повно відображають сутнісит дослідження.

Інформаційні проекти були спрямовані на збирання інформації про певний об'єкт (наприклад, про систему освіти в певній країні), на ознайомлення учасників проекту з цими відомостями, аналіз і узагальнення (наприклад, визначення переваг системи освіти в певній країні), презентацію результатів інформаційного пошуку. 
Студентам спеціальності «Початкова освіта» запропоновано практикоорієнтований проект «Навчальні ігри - це розвага чи ефективний засіб навчання?». Результат діяльності майбутніх учителів початкових класів був зорієнтований на професійні інтереси та чітко визначений із самого початку. Продуктом такого проекту став набір ігор, які мали конкретну навчальну та розвивальну мету, і це знайшло відображення у буклетах, які створили студенти.

Різноманітність видів проектів, тем з курсів педагогічних дисциплін, у ході яких пропонувалася реалізація цих проектів, забезпечувалася тим, що викладачі надавали право вибору студентами тематики й виду проекту. Цей вибір закріплював у свідомості студентів як процес прийняття на себе відповідальності. Також організовувалося групове обговорення всіх ідей, пропозицій, жодна 3 яких не відкидалася, а розглядалася 3 позиції доцільності використання та можливості реалізації в реальному навчальновиховному процесі. У процесі розроблення портфеля навчально-методичних матеріалів спілкування викладача й студентів здійснювалося на суб'єктсуб'єктному рівні. Студенти перетворювалися на суб'єктів пізнавального процесу, ставали активними його учасниками. Під час створення портфеля навчальнометодичних матеріалів періодично організовувалося групове обговорення підготовлених матеріалів, що надавало можливість студентам-магістрантам оцінювати різні об'єкти, що виникали на кожному етапі роботи над розробленням проекту. Студенти оцінювали «чужий» продукт з позиції його доцільності, реалістичності тощо, одночасно оцінювали свою діяльність і свій продукт діяльності.

Залучення студентів до проектної діяльності щодо створення портфеля навчально-методичних матеріалів сприяло становленню у майбутніх учителів системи педагогічних поглядів, засвоєнню умінь проектувати власну діяльність, а також діяльність студентів на творчому рівні, розвитку потреби в постійному самовдосконаленні. Всі проекти, запропоновані студентами, були реалізовані в реальному навчально-виховному процесі на різних курсах у процесі вивчення педагогічних дисциплін. Це надало змогу побачити ефективність підготовленого портфеля навчально-методичних матеріалів, кількісне і якісне його наповнення.

Проведена робота показала, що залучення студентів до проектної діяльності під час вивчення педагогічних дисциплін сприятиме підвищенню ефективності засвоєння навчального матеріалу, формуванню творчого мислення, розвитку педагогічних умінь i зміцненню потреби в самовдосконаленні, якщо дотримуватися таких умов: чітке визначення мети, яка досягається студентами у процесі виникнення ідеї, створення та реалізації проектів, її спрямованість на майбутню професійну діяльність, на самовдосконалення особистості і професіонала; зв'язок проблеми, що розв'язується у проекті, із системою психолого-педагогічних знань, умінь, навичок, які б активізували потреби студентів в індивідуальному відкритті способу розв'язання визначеного педагогічного завдання; планування викладачем системи проектів, визначення місця кожного із них у системі 
вивчення навчальної дисципліни та системі професійної підготовки загалом; створення освітнього середовища, яке б спонукало студентів до самостійного пошуку інформації для реалізації проекту; створення викладачем якісного портфеля навчально-методичних матеріалів як зразка для студентів.

Висновки. Метод проектів є сучасною педагогічною технологією, використання якої створює умови для всебічного розвитку особистості у процесі організації творчої діяльності. Проте ця технологія ще не набула широкого впровадження в навчально-виховному процесі початкової школи. Успіх упровадження проектної технології залежить від усвідомлення вчителями початкових класів іiі значення, знання й дотримання ними алгоритму іï організації.

Отже, робота над проектом - це практика особистісно зорієнтованого навчання в процесі конкретної роботи учня, на засадах його вільного вибору, 3 урахуванням його інтересів. Проектування практично допомагає учням усвідомити роль знань у житті. Знання перестають бути метою, а стають засобом у справжній освіті, допомагаючи опанувати культурні зразки мислення, формувати свої розумові стратегії, що дозволяє кожному самостійно освоювати надбання культури. Для педагога ж - це прагнення знайти виважений баланс між академічними й прагматичними знаннями, уміннями, навичками. Тому нині гостро постає питання про якісну підготовку майбутніх учителів засобами новітніх технологій.

Саме в педагогічному ВНЗ у процесі навчання закладаються основи майбутньої педагогічної техніки, технологічної грамотності та педагогічної майстерності. Така готовність дає можливість майбутньому вчителю впевнено почувати себе у професійній діяльності, швидше адаптуватися в умовах сучасної школи, успішно розв'язувати складні завдання навчально-виховної роботи, вміти вивчати особистісні якості учнів, визначати оптимальні умови педагогічного впливу, глибоко аналізувати результати своєї діяльності.

Перспективи подальших пошуків у напрямку дослідження вбачаємо в розкритті особливостей використання проектної технології у виховній роботі 3 майбутніми вчителями.

\section{Література}

1. Башинська Т. Проектувальна діяльність - основа взаємодії вчителя та учнів / Т. Башинська // Початкова школа. - 2003. - №6. - С.58-59; №7. - С.59-62.

2. Галустов Р. А. Творческие проекты студентов ТЭФ / Р. Галустов, Н. И. Зубов; под ред. Р.А. Галустова. - Брянск : Издательство БГПУ, НМЦ «Технология», 1999. - 152 с.

3. Слькін А. Проектна технологія навчання: данина моді чи нагальна потреба? / А. Слькін // Шкільний світ.- 2007. - №35. - С. 8-10.

4. Курицина В.Н. Метод проектов: вчера, сегодня, завтра / В.Н. Курицина // Образовательная технология как система, объединяющая теорию, практику и искусство. Воронеж: ВГПУ, 2000. - С.59-63.

5. Мацкевич Т. А. Педагогические технологии в развитии детей / Т. А. Мацкевич, Л. Г. Лукоянова // Негосударственное образовательное учреждение школа «Творчество»: опыт становления и тенденции развития / сост. Т. А. Мацкевич, А. П. Шевченко. Самара, 2001. - С. 61-69. 
6. Полат Е. С. Новые информационные технологии в системе образования : [учеб. пособ. для студ. пед. вузов и системы повыш. квалиф. пед. кадров] ; под ред. Е. С. Полат и др. - М. : Изд. Центр «Академия», 1999. - 224 с.

7. Фунтікова О.О. Сучасний погляд на використання методу проектів в організації самостійної роботи студентів поза аудиторією у вищій школі / О. О. Фунтікова // Педагогіка, психологія та медико-біологічні проблеми фізичного виховання і спорту. 2003. - № 11. - С. 17-24.

Стаття надійшла до редакції 12.05.2012 p.

УДК 372.874

В. Ю. Цісарук, асистент, Кременеџький обласний гуманітарно-педагогічний інститут ім. Тараса Шевченка

\section{СТАН ТА СТРУКТУРА ГОТОВНОСТІ ВЧИТЕЛІВ ТЕХНОЛОГІЙ ДО НАВЧАННЯ ШКОЛЯРІВ МИСТЕЦТВУ ХУДОЖНЬОГО ОБРОБЛЕННЯ ДЕРЕВИНИ}

Цісарук В. Ю. Стан та структура готовності вчителів технологій до навчання школярів мистеитву художнього оброблення деревини.

У статті визначено стан готовності вчителів технологій до навчання школярів у галузі художнього оброблення деревини та обтрунтовано структура иієї готовності. Перевірено та описано рівень готовності педагогів загальноосвітніх шкіл Львівської та Тернопільської областей.

Ключові слова:технології, готовність, учитель.

Цисарук В. Ю. Состояние и структура готовности учителей технологии к обучению школьников искусству художественной обработки древесиньл.

B статье определяется состояние готовности учителей технологий $\kappa$ обучению школьников в области художественной обработки древесины и обосновывается структура этой готовности. Проверен и описан уровень готовности педагогов общеобразовательных икол Львовской и Тернопольской областей.

Ключевые слова: технологии, готовность, учитель.

Tsisaruk V. State and structure of teachers' technology readiness to learn the art school art wood processing.

In the article a ready of teachers of technologies condition is determined to the studies of schoolchildren in industry of artistic treatment of wood and the structure of this readiness is grounded. The level of readiness of teachers is tested and described ingeneral lines educational schools of the Lviv and Ternopil areas.

Key words: technologies, readiness, teacher.

Постановка проблеми. У професійно-педагогічній підготовці майбутніх учителів технологій вагоме місце, з-поміж інших, посідає оволодіння різними видами декоративно-ужиткового мистецтва, зокрема художнього деревооброблення. Культурологічний, гуманістичний підхід у вищій педагогічній освіті $€$ невід'ємною складовою методології гармонійного розвитку особистості вчителя як загальнолюдської і професійної цінності [4]. У поєднанні 3 загальнонауковою, мистецтвознавчою, політехнічною, економічною, екологічною освітою та суспільнокорисною практикою художньо-трудова підготовка у галузі оброблення деревини забезпечує гармонічний розвиток, охоплюючи інтелектуальні, емоційні, вольові, ціннісно-орієнтаційні, творчі аспекти формування особистості майбутнього педагога. 